\title{
Comunidade Noiva do Cordeiro: contribuições por meio de elementos de um sistema baseado em uma economia substantiva
}

\author{
LUiz PaUlo Rigueira de Morais ${ }^{1}$ \\ WESCLeY Silva XAVIER ${ }^{1}$ \\ Daniel Calbino Pinheiro ${ }^{2}$ \\ 1 UNIVERSIDADE FEDERAL DE VIÇOSA (UFV), VIÇOSA - MG, BRASIL \\ ${ }^{2}$ UNIVERSIDAde FEDERAL de SÃO JoÃo DEL-REI (UFSJ), SÃo JoÃo DEL-REI - MG, BRASIL
}

\section{Resumo}

Este estudo investigou como ocorreram a formação e a interação de um sistema econômico alternativo na comunidade Noiva do Cordeiro-MG com as dinâmicas da Economia Mercantil. Para atingir este objetivo, realizou-se uma investigação qualitativa valendo-se de uma etnográfica desenvolvida na comunidade rural. Baseado nas teorias da sociologia econômica de Marcel Mauss e de Karl Polanyi, este trabalho sinaliza que os aspectos da dádiva e da reciprocidade nas relações produtivas foram fundamentais para a reprodução de uma forte lógica solidária. Mediante princípios, estruturas e instituições muito próprios, em que o dinheiro tem uma importância bem limitada, os achados apontam que a comunidade desenvolveu um sistema diferenciado reproduzindo múltiplas lógicas econômicas, a despeito da tensão resultante de uma economia de mercado.

Palavras-chave: Economia Solidária. Sociologia Econômica. Etnografia. Comunidade Noiva do Cordeiro.

\section{Noiva do Cordeiro community: contributions from elements of a system based on substantive economy}

\begin{abstract}
This study investigated the formation and interaction of an alternative economic system in the Noiva do Cordeiro-MG community with the dynamics of the mercantile economy. Qualitative research was conducted from an ethnography study developed with the rural community. Based on the theories of economic sociology by Marcel Mauss and Karl Polanyi, this paper points out that the aspects of giving and reciprocity in productive relationships were central to reproducing a strong solidarity logic. Through very own principles, structures, and institutions, in which money plays a very small role, the findings indicate that the community has been able to survive even in the face of the tensions of a market society.
\end{abstract}

Keywords: Solidarity Economy. Economic Sociology. Ethnography. Noiva do Cordeiro Community.

\section{Comunidad Noiva do Cordeiro: contribuciones por medio de elementos de un sistema basado en una economía sustantiva}

\section{Resumen}

Este estudio investigó la formación e interacción de un sistema económico alternativo en la comunidad Noiva do Cordeiro, Minas Gerais, con la dinámica de la economía mercantil. Para lograr este objetivo, se realizó una investigación cualitativa a partir de una etnografía desarrollada en la comunidad rural. Basado en las teorías de la sociología económica de Marcel Mauss y Karl Polanyi, este trabajo señala que los aspectos de la dádiva y de la reciprocidad en las relaciones productivas fueron fundamentales para la reproducción de una lógica solidaria fuerte. A través de principios, estructuras e instituciones propios, en los que el dinero tiene una importancia muy limitada, los resultados indican que la comunidad desarrolló un sistema diferenciado, reproduciendo múltiples lógicas económicas, incluso ante las tensiones de una economía de mercado.

Palabras clave: Economía solidaria. Sociología económica. Etnografía. Comunidad Noiva do Cordeiro. 


\section{INTRODUÇÃO}

A crise econômica que se desenvolveu nos Estados Unidos em 2008 e na Europa em 2011 espalhou-se rapidamente em todo o mundo, indicando problemas estruturais e perturbações inerentes aos sistemas econômicos mercantis (STOREY, BASTERRETXEA e SALAMAN, 2014; PARKER, CHENEY, FOURNIER et al., 2014).

Neste contexto, o resgate de formas alternativas de economia ganhou força. Laville (2014), Storey, Basterretxea e Salaman (2014) apontam que as organizações coletivistas desempenharam um papel importante na transformação e reconfiguração da economia como um todo. Os resultados obtidos pelas organizações solidárias, juntamente com o surgimento de ideias de democracia nas organizações, despertaram, consequentemente, o interesse nos círculos acadêmicos (CHENEY, CRUZ, PEREDO et al., 2014).

Muito embora o tema venha mobilizando o interesse de diversas áreas de estudo, destaca-se a sua pertinência nas investigações acerca dos modos de economia solidária, comumente associados às experiências latino-americanas e francesa, mas também desenvolvidos extraordinariamente em cidades como Nova York (HUDSON, 2018), Boston (LOH e AGYEMAN, 2018), Filadélfia (BOROWIAK, SAFRI, HEALY et al., 2018) e Montreal (GERMAIN, 2010); em países asiáticos como Japão, Tailândia e Coreia do Sul (MATSUI e IKEMOTO, 2015), Iran (BAHRAMITASH, 2014) e Índia (KUMBAMU, 2018); no continente africano, especificamente na África do Sul (SATGAR, 2011); e em países europeus como Eslováquia (DUBCOVÁ, GAJDOVÁ e GRANCICOVÁ, 2016), Grécia (PAPADAKI e KALOGERAKI, 2018) e Suíça (KALOGERAKI, PAPADAKY e ROS , 2018).

A relevância do tema da economia solidária advém da complexidade da sua organização e de sua proposição política inovadora, que capta e se serve de elementos oriundos de atividades mercantis, não mercantis (a redistribuição) e não monetárias (a reciprocidade), produzindo e distribuindo bens ou serviços (SERVA, 2002; LÉVESQUE, 2007; FRANÇA FILHO, 2013; LAVILLE, 2016).

Conforme a complexidade estruturante das formas de Economia Solidária, a sua análise exige uma perspectiva que contemple a imbricação de aspectos econômicos, sociais e políticos de sua organização. Nesse sentido, a Sociologia Econômica, em especial na vertente francesa de Marcel Mauss, e a teoria da reciprocidade de Karl Polanyi, constitui instrumentos teóricos eficientes para a compreensão da lógica organizacional da economia solidária.

As perspectivas de análise abertas pela sociologia da dádiva, de Mauss, e pela teoria da reciprocidade, de Polanyi, parecem contribuir de maneira efetiva para a compreensão das organizações baseadas na Economia Solidária, configurando um olhar inovador sobre as interações que se realizam nesse contexto organizacional (FRANÇA FILHO e DIZIMARA, 1999; SERVA, 2002; VIZEU, 2009; LAVILLE, 2014). Enquanto o processo de dádiva presente no cotidiano das organizações de Economia Solidária revela ser o vínculo de entendimento desses tipos organizacionais; a reciprocidade estabelece os laços necessários para que a dinâmica da dádiva seja empreendida.

Assim, o presente artigo tem por objetivo investigar a estrutura social de um modo de produção e de vida substantivo, que incorpora a vida social de uma maneira geral (SOBEL e POSTEL, 2016). Tendo por base a Sociologia Econômica, busca-se compreender como ocorreram a formação e a manutenção do sistema de Economia Solidária observado na comunidade Noiva do Cordeiro (MG).

A comunidade Noiva do Cordeiro chama a atenção por sua forma única de organização social e de produção. Fortemente marcada por uma série de desventuras que remontam à sua origem em 1891, a comunidade desenvolveu um sistema econômico que opera produtivamente pelo associativismo produtivo, e politicamente pela organização e mobilização dos seus membros, investindo prioritariamente em prol dos valores, das instituições e das formas de comportamento. A propriedade comum dos meios de produção; a convivência nas casas dormitório; a produção comunal de moradias; a alta coesão dos seus membros são fatores que desafiam a visão a-histórica e naturalista que considera a economia um fenômeno autorregulado e independente dos processos sociais (MAUSS, 2008, 2013; POLANYI, 2011, 2012).

Este trabalho objetiva, teoricamente, contribuir com elementos para uma interpretação da economia solidária do ponto de vista da Sociologia Econômica. Especificamente, ao destacar as nuances da inter-relação da dádiva e da reciprocidade características das formas de Economia Solidária, abre-se espaço para mais uma possível interpretação sociológica, capaz de compreender as formas alternativas de economia híbrida e sua sobrevivência em meio ao sistema econômico mercantil.

Empiricamente, constata-se que o fenômeno da comunidade de Noiva do Cordeiro ainda está por ser suficientemente investigado no âmbito acadêmico. Dentre os poucos trabalhos voltados para este tema, destacam-se os estudos de 
Fazendeiro (2016), que identificou o processo de transição de uma religião convencional para novas práticas espirituais, bem como os de Roese (2015), Roese e Schultz (2010), e Schultz (2013), que analisaram a dissidência religiosa e o modo alternativo de vida da comunidade.

\section{A Sociologia Econômica e as Organizações de Economia Solidária}

Desde 1980, um dos campos que têm experimentado maior crescimento nas ciências sociais é o da sociologia econômica (SERVA e ANDION, 2006; LÉVESQUE, 2007). Em uma perspectiva internacional, as suas manifestações foram marcadas pela criação da Society for Advancement of Socio-Economics, nos Estados Unidos, em 1989, pela rede temática em sociologia econômica no interior da Associação Francesa de Sociologia, pelo lançamento do Handbook da Economia Sociológica em 1994, além das várias revistas acadêmicas e a realização anual de diversos congressos internacionais.

No Brasil, embora o movimento tenha chegado mais tarde, destacam-se como marcos importantes a revista Sociedade $e$ Estado, da UnB, que publicou em 2002 a primeira coletânea de trabalhos sobre Sociologia Econômica no Brasil. Além desta publicação, nos anos de 2004 e 2005 o Encontro Anual da Associação de Pós-Graduação e Pesquisa em Ciência Sociais (Anpocs) promoveu uma seção de apresentação de trabalhos sobre o tema "análise sociológica dos fenômenos econômicos". Em 2005, a Revista de Administração de Empresas lançou o Fórum Especial de Sociologia Econômica (SERVA e ANDION, 2006). Ademais, dois meta-estudos apontam para a presença de mais de 49 trabalhos que utilizam a Sociologia Econômica para a sua aplicação no campo da Administração no Brasil, entre os anos de 1985 e 2008 (MACHADO e NASCIMENTO, 2012) e 2006 a 2015 (MOREIRA, 2016).

Do ponto de vista histórico, a sociologia econômica tem suas raízes entre os autores clássicos como Émile Durkheim, Max Weber, Karl Marx, Georg Simmel, Marcel Mauss e Karl Polanyi. De modo correlato, a perspectiva institucional faz-se presente já no nascimento da Economia, tanto na Escola Clássica Inglesa - Adam Smith, David Ricardo, John Stuart Mill -, como na Escola Histórica Alemã - Wilhelm Roscher, Bruno Hildebrand e Karl Knies - (SERVA, 2002; MARTES, LOUREIRO, ARAMOVAY et al., 2007).

Porém, entre 1920 e 1960, o diálogo entre a sociologia e a economia ficou negligenciado (SERVA, 2002). Tendo reservado à teoria econômica o estudo do comportamento individual racional, à sociologia restou compreender os motivos, sejam eles individuais ou sociais, orientadores do comportamento econômico (SWEDBERG, 1994). Contudo não se deve perder de vista que o declínio das abordagens apoiadas na intersecção desses dois campos não significou o abandono dos temas econômicos pelos sociólogos. Particularmente, Karl Polanyi e Marcel Mauss contribuíram proficuamente à Sociologia Econômica com seus escritos nesse período (MARTES, LOUREIRO, ARAMOVAY et al., 2007).

Na década de 1980, a sociologia econômica ressurge com intensidade, voltando seu interesse para as bases deixadas pelos seus precursores, ou seja, os estudos dos fenômenos econômicos à luz de uma abordagem sociológica. A sociologia econômica, por meio de diferentes correntes, passa a contrapor a ciência econômica neoclássica, demonstrando que os fenômenos econômicos são construções sociais e institucionais (SERVA e ANDION, 2006).

Trata-se de uma construção social, uma vez que a ação econômica não pode ser completamente explicada por razões individuais: ela passa por mediações e redes sociais (GRANOVETTER, 2000). Da mesma forma, é uma construção institucional, porque o comportamento econômico supõe diretrizes políticas e normativas que vão dos arranjos sociais fundamentais até os hábitos mentais predominantes (LAVILLE, 2016).

Do ponto de vista conceitual, a sociologia econômica pode ser definida como um conjunto de teorias que se esforçam por explicar os fenômenos econômicos tomando por base elementos sociológicos. Busca-se estudar o econômico na sociedade (fenômenos econômicos) como a maneira pela qual esses fenômenos influenciam o resto da sociedade (fenômenos economicamente condicionados) e o modo pelo qual o restante da sociedade os influencia (fenômenos economicamente relevantes) (SWEDBERG, 1994).

Dentre as diversas correntes teóricas que buscam compreender os fenômenos econômicos da ótica sociológica, distinguem-se duas grandes vertentes, a inglesa e a francesa, com as suas diversas ramificações. A corrente inglesa abrange a Nova Sociologia Econômica, representada por Mark Granovetter, Neil Fligstein; os Evolucionistas e neoschumpeterianos, representados por Richard Nelson, Sidney Winter e Christopher Freeman; os neocorporativistas, aqui ilustrados nas figuras de Philippe Schmitter, Wolfgang Streeck e J. Rogers Hollingsworth; os novos institucionalistas, como John Galbraith, Gunnar Myrdal e 
Geoffrey Hodgson; e, por fim, a socioeconomia, representada por Amitai Etzioni e Paul Lawrence. Os estudos elaborados nessa corrente, em sua maioria, adotam o ponto de vista objetivista de uma teoria das relações sociais, e se caracterizam pelo pouco espaço dado à ação, no sentido de transformação da ordem social.

Já os autores francófonos, mais relacionados à sociologia e à antropologia, são representados pelos que seguem o pensamento de Mauss (Alain Caillé, Jacques Goudbout); pela escola da regulação (Michel Aglietta, Robert Boyer, Alain Lipietz); pela escola da grandeza (Luc Boltanski, Laurent Thenévot); das convenções (Olivier Favereau, Andre Orlean, Robert Salais); e pela economia solidária e plural (Jean-Louis Laville, Benoît Lévesque). Estes autores chamam a atenção para a emergência de novas práticas econômicas que poderiam ultrapassar os limites dos modos tradicionais de regulação (KIRSCHNER e MONTEIRO, 2002; LÉVESQUE, 2007).

Nesta última variante, a Economia Solidária caracteriza-se pela abordagem das dimensões não monetárias e não mercantis da economia contemporânea, constituindo-se em instituições intermediárias que articulam o político e o econômico (LAVILLE, 1994). Diferentemente da economia formal, que estuda o comportamento humano enquanto relações fins em uma dinâmica de trocas mercantis, o campo de estudo da economia solidária inclui em suas análises não somente as atividades mercantis, mas também as atividades de redistribuição, de reciprocidade, decorrentes da produção ou da distribuição de um bem ou de um serviço.

Trata-se de pensar outra forma de produção e distribuição de riqueza que mobilize os dois registros da solidariedade democrática, combinando a solidariedade redistributiva com uma de reciprocidade para reforçar a capacidade de auto-organização da sociedade (FRANÇA FILHO, 2013; LAVILLE, 2016).

Assim, a análise das iniciativas geradas pelas organizações solidárias permite compreender como as associações de funcionamento democrático favorecem a hibridação de uma grande variedade de recursos. Se essa construção conjunta é observável nas iniciativas emergentes, ela supõe um funcionamento engendrado por uma democracia plural que se baseia não somente na representatividade, mas também na deliberação e numa governança apropriada (LÉVESQUE, 2004).

Um aspecto singular da Economia Solidária deve-se à função da dádiva, dificilmente identificada nas instituições mercantis. Já o papel do associativismo é o de concretizar as instituições fundadas na solidariedade econômica (FRANÇA FILHO e DZIMIRA, 1999; CASTANHEIRA e PEREIRA, 2008).

O associativismo manifesta-se como uma forma de envolvimento solidário dos membros de um grupo na prática de atividades econômicas correntes (serviços e modos de troca, produção, comércio, consumo, poupança), coincidindo, portanto, com a noção de atualidade de Mauss (2012), que defende a possibilidade de instituições basearem-se em dinâmicas solidárias (LAVILLE, 2014).

O aporte de Mauss complementa-se com o de Polanyi (2011), que substitui a abordagem formal da economia ortodoxa por uma abordagem substancial e reconhece, além do mercado, princípios de redistribuição, administração doméstica e reciprocidade. As práticas estudadas nos serviços das economias plurais consideram a hipótese de impulso de hibridação em uma perspectiva de Economia Solidária (SABOURIN, 2008; VIZEU, 2009; LAVILLE, 2014).

\section{A Dádiva e a Geração de Vínculo em Marcel Mauss}

As motivações para trocas em sociedades alternativas à lógica mercantil foram objetos de estudo do antropólogo francês Marcel Mauss, particularmente sob o caráter voluntário da ação livre e retribuição obrigatória, a dádiva, a partir do texto seminal Ensaio sobre a Dádiva, publicado em 1925. A discussão do valor heurístico da interpretação da dádiva serviu de fundamento para um novo paradigma nas ciências sociais, com uma severa crítica ao pensamento utilitarista vigente que subordinou e reduziu toda ação social a uma questão de escolha economia racional e estratégica (LÉVESQUE, 2007; RIGO e FRANÇA FILHO, 2017).

Mauss $(2008,2013)$ destaca que, nas economias e nos direitos que precederam a sociedade capitalista, desde a sua forma mais rudimentar, não se observam trocas de bens, de riquezas e de produtos no decurso de um mercado regulador. $\mathrm{O}$ que se via eram coletividades que exerciam das trocas para atenderem suas necessidades de subsistência. Além disso, as trocas executadas nessas sociedades não eram exclusivamente de bens e riquezas ou úteis economicamente. Envolviam, sobretudo, a troca de presentes, as amabilidades, os ritos, as danças, o que fazia do mercado de bens materiais somente um dos termos de um contrato social, mais geral e permanente que as transações comerciais. 
Com base nessa análise, definiu que as dádivas são o conjunto das coisas, materiais e imateriais; quando transmitidas, carregaram consigo a obrigatoriedade de retribuição, não necessariamente imediata ou equivalente, mas em forma de novas dádivas que levariam o sistema a circular com melhor fluidez, baseando-se nos vínculos que se formaram na sociedade (MAUSS, 2008). A dádiva compreende três momentos: doação, recepção e retribuição, e opera de modo horizontal na sociedade em prol de um laço social. A lógica da dádiva obedece a um tipo de determinação social específica; ao mesmo tempo livre e obrigada, a doação é essencialmente paradoxal (GODBOUT, 1998; CAILLÉ, 2002; FRANÇA FILHO, 2004).

Mauss (2008) observou que o contínuo processo de prestações e contraprestações de serviços entre os membros dessas sociedades ocorria majoritariamente de forma voluntária e com a utilização de presentes, sendo uma transação aparentemente unilateral sem expectativa de contrapartida imediata e equivalente. Contudo, o processo de troca de presentes, ou dádivas, acabava sendo rigorosamente obrigatório, pois, não sendo retribuída a dádiva, conflitos sociais poderiam ser gerados, uma vez que se leve em conta que nenhum presente é dado de forma gratuita (GRAEBER, 2014). O processo de dar-receber sem retribuir cria uma relação de caridade assistencialista, na qual quem recebe continua dependente de quem doa. E ainda, no mercado convencional, o processo de vender-pagar não cria laços de dependência, ao contrário, encerra a obrigação e a relação social (LAVILLE, 2014; FAVARIN, 2018).

Por isso, Mauss (2008) destaca que, ao passo que a lógica do mercado funciona pela equivalência, em um movimento de "dar-pagar", na dádiva vige a lógica da troca desigual, ou seja, os bens não têm necessariamente o mesmo valor no processo de doação e retribuição. O valor mais importante é o relacional, o que gera o vínculo da dívida e das relações continuadas.

O processo de troca de dádivas ocorre por si mesmo, e está intimamente ligado ao homem como ação que rompe o estado de solidão e gera a sensação de pertencimento, de reconhecimento como parte integrante do grupo. O sistema de dádivas não apenas cria vínculos sociais como também os alimenta. Desde os presentes pessoais até as doações para grandes catástrofes, a dádiva contribui para o rompimento do isolamento e para o reconhecimento de uma identidade (GODBOUT, 1998; CAILLÉ, 2002).

Segundo Mauss (2008), os atores no sistema de dádivas também demonstram um comportamento bastante específico quanto à percepção de valor das dádivas. Tendem a negar explicitamente o valor das doações tendo em vista garantir a não obrigatoriedade de quitação da dívida e a manutenção de certo vínculo pessoal. Esta seria a maneira de possibilitar ao receptor retribuir a dádiva recebida com outra dádiva também genuína e não com um mero pagamento. 0 sistema de dádivas, portanto, se diferencia da concepção economicista baseada no ganho contínuo, no contrato e na garantia de retorno. Ou seja, à medida que o sistema econômico mercantil se blinda de todas as maneiras possíveis da incerteza, no sistema de dádivas a incerteza estabelece os vínculos entre seus atores (GODBOUT, 1998).

Mauss (2013) destaca que, de alguma forma, os antigos princípios baseados na dádiva ainda se reproduzem por intermédio de muitas ações sociais que buscam reduzir desumanidades e assimetrias provenientes das novas práticas de mercado. Uma sociedade baseada nos princípios da dádiva caracteriza-se pela humanização e pela solidariedade das relações de trabalho, em resguardo dos vínculos sociais. Nela, o indivíduo tem a percepção de si próprio e de sua importância relativamente ao grupo, viabilizando o estabelecimento de relações mútuas e cooperativas, pautadas em valores grupais e não nos valores monetários característicos do capitalismo.

Assim, a teoria da dádiva de Mauss permite compreender como as trocas refletem e recriam subjetividades e relações sociais, bem como reconfiguram a própria compreensão social da natureza de alguns objetos. $O$ estudo concreto da vida social permite inferir os diversos aspectos, as motivações estéticas, morais, religiosas que constituem a vida coletiva (CARRIER, 1991).

Longe de desconsiderar as motivações utilitárias que influenciam a conduta humana, a teoria abre espaço para a identificação de outros elementos, menos instrumentais, que explicitem os comportamentos individuais e coletivos, em especial nas organizações coletivistas (SERVA, 2002; RIGO e FRANÇA FILHO, 2017).

Ademais, condicionada pela predominância do fortalecimento dos laços entre seus membros, a Economia Solidária pode ainda ser considerada como propensa à manifestação e análise da troca-dádiva. Isso se explica, principalmente, pelo fato de o cálculo utilitário ser uma referência inadequada para a análise das relações interpessoais nessas organizações, que emergiram nas últimas décadas endereçadas ao retorno de um humanismo perdido com a lógica de mercado (VIZEU, 2009). 


\section{Ascensão do Mercado e Economia Substantiva em Karl Polanyi}

Karl Polanyi, em seu livro A grande transformação de 1944, deu uma grande contribuição à consolidação da Sociologia Econômica empreendendo uma análise histórica da concretização do princípio econômico que funda a economia de mercado. Contrariamente à ideia do naturalismo histórico de um mercado espontâneo, suas análises permitem pensar a economia como imersa (embeddedness) na sociedade, afirmando a inseparabilidade entre os aspectos econômico e social (LÉVESQUE, 2007; MARTES, LOUREIRO, ARAMOVAY et al., 2007; CORAGGIO, 2014).

Segundo o intelectual Húngaro Karl Polanyi (2011), antes da Primeira Revolução Industrial, o mercado constituía apenas uma parte das relações sociais, um dos mecanismos de organização das sociedades. A vida econômica estava inserida na organização social e política, havendo mais espaço para transações econômicas não monetárias.

Com o desenvolvimento industrial, no entanto, o comércio infiltrou-se na vida cotidiana, fazendo emergir uma economia hegemônica de mercados. Novas relações importantes para o sistema do capital foram institucionalizadas, somando-se aos mecanismos de mercado o controle da oferta e da demanda de recursos (POLANYI, 2012).

Assim, a economia formal é convertida em sociedade de mercado, desenraizando a economia substantiva das instituições sociais. Neste contexto, em vez de a economia estar embutida nas relações sociais, são as relações sociais que estão incrustadas no sistema econômico. No entanto, o capitalismo liberal com suas características intrínsecas, seu reducionismo econômico mercantil, era incompatível com a equidade social. A mirada aparentemente racional da lógica competitiva do mercado reduz drasticamente os elementos de responsabilidade individual frente as forças objetivas do intercâmbio mercantil, e não realiza, em hipótese alguma, a promessa de harmonia social e bem-estar coletivo que dizia incorporar (SUBIRATS, 2014).

Logo, identifica-se uma contradição do sistema de mercado como regulador, por gerar um duplo movimento. Por um lado, a expansão da sociabilidade capitalista pelo intercâmbio mercantil, por outro, suas formas desiguais e autodestrutivas, que geram um contramovimento de autoproteção, valendo-se de formas econômicas para além do mercado (SCHNEIDER e ESCHER, 2011), O avanço recente das formas de Economia Solidária em versas partes do mundo, como antecipado por Polanyi (2012), indica essa reação.

A Economia Solidária, definida também por economia substantiva, não é construída desde cima, e sim com práticas sociais que apontam a reinserção da economia em normas democráticas. Lança-se mão de outro significado: entender o processo de intercâmbio entre indivíduos em busca de sustento e sobrevivência (POLANYI, 2011, 2012). A organização básica que permite a integração econômica e sua validação provém da esfera social e das instituições presentes e construídas nela. Resgata-se, assim, a questão do enraizamento, um dos princípios da Sociologia Econômica. A proposta é que a sociedade seja pensada como um sistema que funciona de acordo com as suas próprias leis, e a economia seja controlada por ela e, em sua função, ou seja, incrustada e limitada por regras institucionais que conectem o seu tecido moral (OGANDO, 2011).

Na economia substantiva, isso é possível, uma vez que as práticas econômicas incluem não somente as atividades mercantis, mas princípios de redistribuição, de administração doméstica e de reciprocidade (LÉVESQUE, 2007; LAVILLE, 2014). Assim, enquanto o movimento de redistribuição relaciona-se à centralização produtiva para posterior distribuição, verificada pela divisão do trabalho, dos impostos e da assistência social, o movimento conhecido como "domesticidade" associa-se à circulação de bens entre diferentes pontos dos sistemas sociais, sendo um padrão influenciado pelo interesse do ganho e normalmente praticado nas estruturas de mercado. Já o movimento de reciprocidade refere-se à circulação de produtos mediante o movimento de bens dentro de um círculo comunitário, seja ele impulsionado por graus de parentesco, amizade ou envolvimento associativo para fins produtivos (SCHNEIDER e ESCHER, 2011).

No contexto da Economia Solidária, a noção da reciprocidade alinha-se com a da dádiva. Embora Mauss tenha considerado a dádiva como oposta à troca mercantil e demonstrado a sua essência tríplice expressa na dinâmica de dar, receber e retribuir, não chegou a teorizar sobre a reciprocidade (SABOURIN, 2008).

Contudo, Mauss inferia que a dádiva sem reciprocidade deve ser evitada, pois a caridade sempre magoa aquele que a aceita, e todo o esforço da moral tende a suprimir o patrocínio inconsciente e injurioso do rico processo da dádiva (LAVILLE, 2014). Logo, neste trabalho, parte-se do pressuposto de que, no seio das organizações de economia substantiva, a solidariedade é uma construção que advém do processo de dar-receber-retribuir. 
Observa-se um grande avanço no número de publicações sobre a Economia Solidária, muito embora ainda não se dê a devida importância à compreensão da relação da dádiva com a reciprocidade neste âmbito de estudo. Se, por um lado, os estudos integrativos indicam que a temática possui mais de 246 artigos publicados nos principais periódicos da área (CALBINO e PAULA, 2013; ALVES, FLAVIANO, KLEIN et al., 2016; PINHEIRO, 2016) e 100 grupos de pesquisas cadastrados no CNPq (FERRARINI, GAIGER e SCHIOCHET, 2018), por outro lado, o número de trabalhos voltados para a compreensão da relação da dádiva e da reciprocidade, da perspectiva teórico-empírica, limita-se a três (KIRSCH, 2007; DARÓS, 2016; FAVARIN, 2018).

Dentre as contribuições, Kirsch (2007) aponta para as formas como a dádiva e a reciprocidade manifestam-se nas relações de incubação entre a universidade e os empreendimentos de economia solidária. O estudo de Darós (2016) analisa as respectivas dimensões desde o seu impacto no conceito de felicidade no campo da Economia Solidária. Já o recente trabalho de Favarin (2018) examina, da ótica da dádiva e da reciprocidade, as iniciativas de finanças solidárias espalhadas pelo país.

Os trabalhos supracitados apontam a emergência da perspectiva da Sociologia Econômica para a compreensão do fenômeno da Economia Solidária. O presente trabalho se insere neste âmbito de questionamento tendo como objeto de estudo a comunidade centenária Noiva do Cordeiro, que reforça.

\section{PERCURSO METODOLÓGICO}

entendimento da organização social e produtiva da comunidade Noiva do Cordeiro é de difícil apreensão, já que sociedades são objetos de complexa sistematização. Por mais que a comunidade apresentasse elementos de uma organização produtiva, de uma comuna, e vivesse sem um sistema normativo formal, não negava sua participação no modo produtivo capitalista.

Entender a história da comunidade era essencial para compreender a organização formada. Contudo as motivações envolvidas em cada ação, os pontos específicos da história do grupo, e a relação de cada membro com a organização seriam compreensíveis somente mediante a união de diversas perspectivas coletadas e exigiriam contato intenso com a comunidade. Dessa forma, a etnografia mostrou-se o método mais apropriado para entender de perto essa realidade.

Segundo Mattos (2011), a etnografia é um método qualitativo que busca apreender os modos como as pessoas conduzem suas vidas no intuito de atribuir significados e sentidos às ações observadas.

Dessa forma, a pesquisa que deu origem a este artigo teve como orientação o estranhamento e a aproximação entre duas realidades produtivas e econômicas, uma amplamente conhecida como economia capitalista, e outra ainda pouco explorada, aqui denominada "Sistema Econômico da Comunidade Noiva do Cordeiro". Durante a permanência na comunidade, foi necessário orientar-se por maior distanciamento e aproximação entre as duas lógicas e realidades, observando suas tradições próprias, seu sistema produtivo, e as interações econômicas subjacentes a essa dinâmica.

Magalhães, Santos e Boeira (2016) explicam que o método etnográfico nas organizações enfrenta os entraves de estudos interdisciplinares, em que as concepções de um campo podem não ser totalmente compatíveis com as concepções de outro. Dessa forma, uma base sociológica e antropológica mínima deveria ser construída antes que o pesquisador de organizações utilizasse o método etnográfico, reduzindo o distanciamento entre as duas disciplinas. Travancas (2006) descreve elementos centrais da fase preparatória do estudo etnográfico e aponta serem essenciais: (1) um amplo levantamento bibliográfico sobre o tema estudado e sobre o grupo em questão; (2) a negociação quanto ao acesso e a permanência no campo; e (3) a construção das ferramentas de pesquisa, como os diários de campo e as perguntas-chave que o pesquisador busca responder com o estudo.

O levantamento bibliográfico neste estudo focou em materiais disponíveis sobre a comunidade, em artigos e reportagens já publicados sobre o grupo, e em teorias que pudessem explicar minimamente o comportamento da comunidade e os seus vínculos tão fortes. A negociação quanto ao acesso à comunidade se deu em 2016, um ano antes do início do trabalho de campo. Nesse intervalo, ocorreram quatro visitas, objetivando compreender alguns elementos das estruturas produtivas e da história do local. Essas visitas foram ainda importantes para definir os detalhes da vivência na comunidade. 
No decorrer da pesquisa, a interação com os membros ocorreu de maneira gradual, conforme a participação e o acompanhamento de cada um dos grupos responsáveis pelas atividades principais da comunidade. Dessa forma, além de conhecer as dinâmicas econômicas, foi possível conhecer todos os membros envolvidos ativamente nelas. As abordagens para coleta de dados foram sempre informais, evitando entrevistas com os membros da comunidade. Como habitual em etnografias, a ferramenta principal de registro de dados foi o diário de campo, armazenando observações sobre as situações vividas.

Clifford e Gonçalves (2011) destacam que a participação do etnógrafo nas atividades serve para que, além de uma maior aceitação do grupo, o pesquisador possa ter, sobre este, um maior entendimento. Além disso, a participação nas atividades dá ao pesquisador a chance de entender a linguagem do grupo, assimilar-se a ela, e depois traduzi-la para termos científicos. Dessa forma, o processo etnográfico abre ao pesquisador a possibilidade de estabelecer discussões entre uma lógica já conhecida pela comunidade científica e uma lógica ainda desconhecida, buscando, com essa interlocução, descrever, entender e aprender com esse sistema até então desconhecido.

A permanência na comunidade iniciou-se em julho de 2017 e se estendeu por três meses. Com exceção dos momentos de escrita, que geralmente ocorriam à noite, todo o resto do tempo era dedicado à vida coletiva e às atividades desenvolvidas na comunidade. Em momentos muito específicos, conversas formais eram desenvolvidas com personagens chave do processo de mudança. Nos períodos de convivência, o acesso à conduta e ao comportamento dos indivíduos foi bastante limitado. Cada família possui sua própria realidade, desafios e preocupações, e por não compor os objetivos desta pesquisa conhecer o cotidiano individual das famílias, mas sim o coletivo, as dinâmicas familiares tradicionais foram pouco exploradas.

As análises valem-se de categorias apriorísticas, do arcabouço teórico aqui utilizado, assim como de categorias a posteriori, emersas das abstrações acerca da vivência e atribuições de sentido a muitas das dinâmicas observadas. Por fim, a etapa de afastamento deu-se de forma gradual, uma vez que, mesmo após coletados os dados, foram mantidos contatos e realizadas três visitas à comunidade.

\section{Descrição Etnográfica}

Noiva do Cordeiro foi fundada em 1891 por Maria Senhorinha de Lima e seu segundo marido, Francisco Fernandes. Incomum à época, Senhorinha largou um casamento arranjado e, junto com Francisco, foi viver em um terreno mais afastado, herdado pelo marido, onde a comunidade se formou. $\mathrm{O}$ terreno localiza-se no interior de Minas Gerais, em uma zona rural chamada de região de "Cordeiros", cerca de $100 \mathrm{~km}$ da capital mineira e a $16 \mathrm{~km}$ da cidade mais próxima, Belo Vale. A comunidade tem aproximadamente vinte hectares e se posiciona como uma das mais afastadas da área urbana do município.

Inicialmente, dois pontos de inflexão marcaram a comunidade. O primeiro diz respeito à localização geograficamente isolada do terreno em relação às outras cidades. $O$ segundo, de aspecto religioso, diz respeito ao fato de Maria Senhorinha abandonar seu primeiro marido e, em virtude disso, passar a ser considerada adúltera pelos povoados do entorno - católicos, em sua maioria. A situação religiosa veio a se agravar ainda mais quando o padre de uma das comunidades próximas excomunga o casal e suas quatro gerações futuras, intensificando o isolamento da família em relação aos vizinhos e às comunidades adjacentes. Com o passar do tempo, este isolamento geográfico-social constituiu-se em um elemento de proteção para a comunidade de Noiva do Cordeiro frente aos processos de integração puramente mercadológicos.

Maria Senhorinha e Francisco tiveram nove filhos, dentre os quais, dois tiveram papel fundamental na formação da atual comunidade Noiva do Cordeiro: Francisco Fernandes Filho e Maria Matusinha. Foram os únicos filhos que não dividiram suas terras e que permaneceram no local com suas famílias. Francisco Fernandes Filho já é falecido; deixou doze filhos, incluindo Delina Fernandes, hoje matriarca da comunidade.

O terreno da comunidade é posse dos herdeiros destes dois filhos. Apesar da ausência de inventário, as questões de direito de posse da propriedade nunca foram motivo de conflito entre os herdeiros, que viram na situação uma oportunidade para o uso coletivo da propriedade e de seus recursos. Ela serve atualmente de moradia para mais de trezentos membros, descendentes diretos e indiretos do casal fundador. Devido ao intenso número de casamentos entre as próprias famílias, a população tornou-se fortemente homogênea, e hoje seus membros possuem, quase que integralmente, os mesmos antepassados. 
Figura 1

Imagem aérea da comunidade

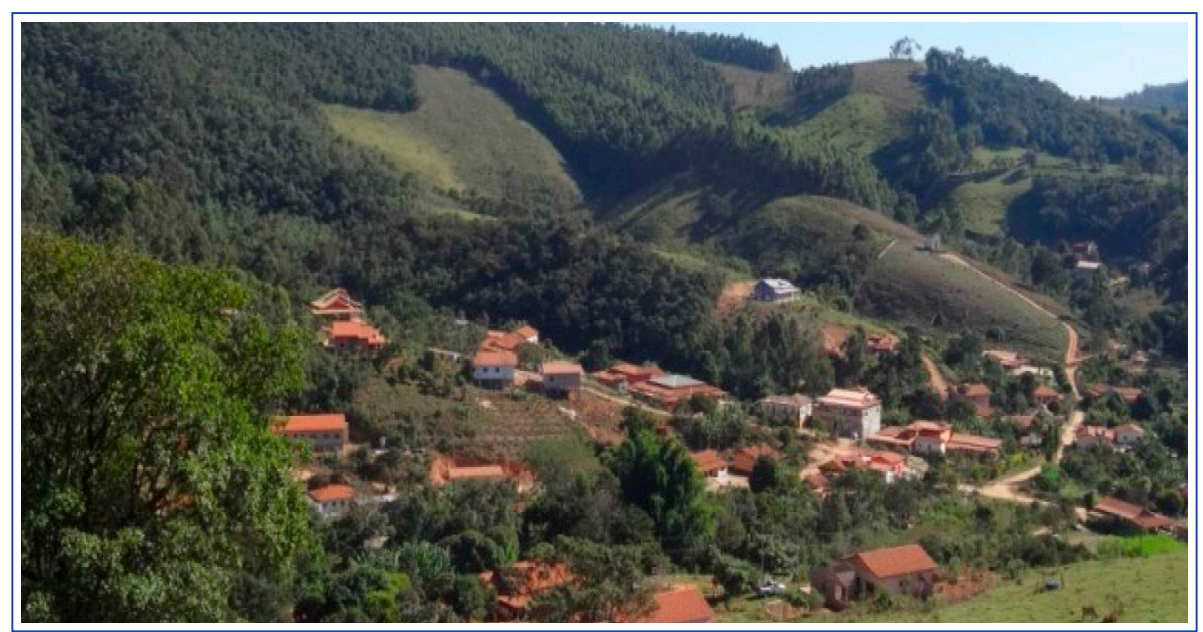

Fonte: Acervo dos autores (2019).

Delina Fernandes, filha de Chico e neta de Maria Senhorinha, também figura como personagem de extrema importância na história da comunidade Noiva do Cordeiro. Nascida em 1948, vivia com seus pais na atual propriedade da comunidade. Em sua juventude, aos 14 anos, aceitou casar-se com Anísio, um pastor recém-chegado na região. Pastor Anísio, como era conhecido por todos, foi o fundador de sua própria igreja evangélica, a "Noiva do Cordeiro". A igreja fundada por Anísio, hoje vista pelos membros da comunidade como extremamente rígida e restritiva, passou a ser seguida por praticamente todos os habitantes da comunidade.

Dentre os inúmeros ditames religiosos impostos aos membros, figuravam: a proibição do controle da natalidade; o controle no estilo de vestuário; a proibição de músicas; os jejuns; a proibição de corte de cabelo pelas mulheres, etc. A impossibilidade de trabalhar fora da comunidade levou a família de Delina, seus irmãos e demais familiares a péssimas condições de vida, tanto sociais, quanto laborais. Somou-se a isso o recrudescimento do isolamento social devido às diferenças de pensamento religioso em relação às comunidades vizinhas, ainda predominantemente católicas.

Poucos anos antes do falecimento de Anísio, em 1995, Delina abandonou a religião, levando a maior parte da comunidade a tomar também a mesma decisão. Delina, então, usou dessa autoridade legítima para estimular um comportamento recíproco entre os membros de sua família. Dentre as iniciativas para encontrar soluções aos problemas enfrentados, destaca-se a disseminação de uma lógica de vivência e consumo coletivos, para a qual foram chamados de volta os núcleos familiares que enfrentavam dificuldades financeiras nas cidades, em 1998, em que se dividiu o pouco que ainda conseguiam produzir de alimento no local.

As famílias começaram a unir suas produções, suas hortas, seus trabalhos de costura e todo o serviço de infraestrutura. Com o uso de linhas de financiamento do governo, a comunidade adquiriu terras para plantios voltados ao consumo coletivo, bem como para a produção de pimenta biquinho em larga escala, principal produto comercializado pela comunidade. Ademais, o trabalho externo à comunidade, sobretudo realizado na Região Metropolitana de Belo Horizonte e exercido majoritariamente pelos homens da comunidade, passou a representar importante fonte de renda para a compra de materiais e recursos produtivos, enquanto o trabalho rural, o trabalho manufaturado, e a organização da comunidade ficaram a cargo dos demais membros, mulheres em sua maioria. A produção agrícola tornou-se conjunta e de responsabilidade de todas as famílias, de modo que, do preparo à colheita, tudo fosse produzido e distribuído comunitariamente. Outras formas de produção coletiva foram criadas, profissionais de costura uniram-se sob uma mesma produção destinada ao consumo interno e à comercialização, dando origem à "fábrica", que atualmente destina-se à produção de itens para o mercado de pet shops. 
Figura 2

Mapa das estruturas físicas principais da comunidade

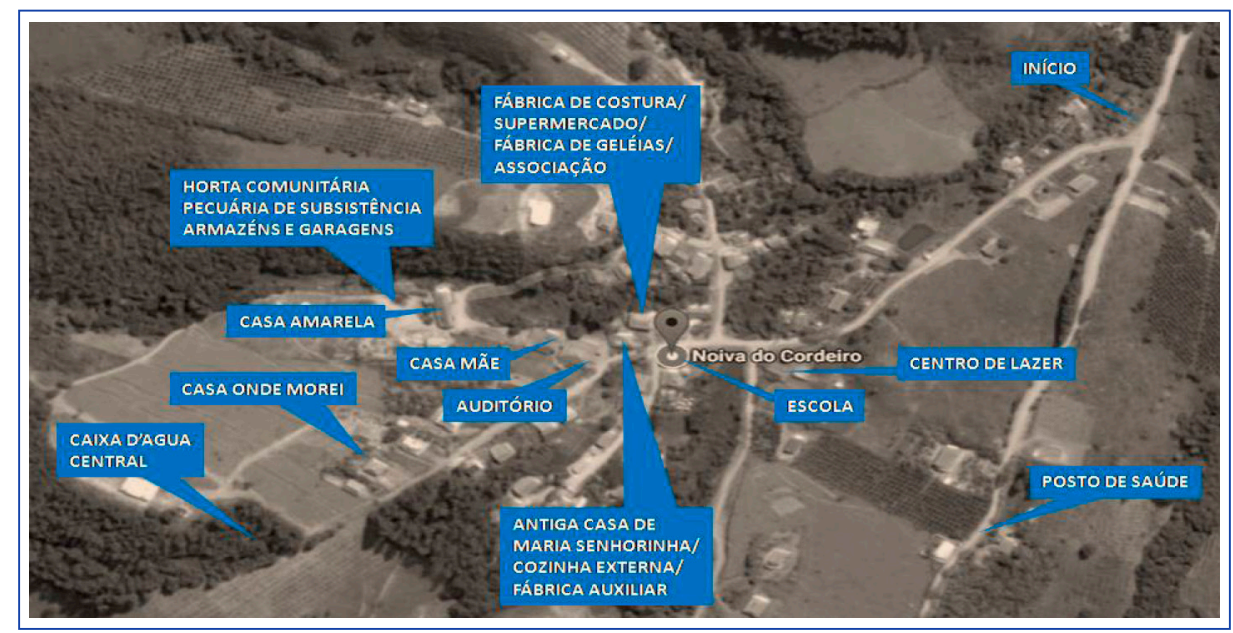

Fonte: Adaptado do Google Maps (2019).

Para além da produção e distribuição comunal, outros arranjos proporcionaram o fortalecimento da lógica coletiva da comunidade, como a associação criada pelos moradores, que se configura na instância em que todas as decisões são tomadas por consulta coletiva, e que atua também na captação de recursos revertidos em benefícios diretos para a comunidade, e no apoio aos membros em diversas esferas. Da associação surgiram os grupos responsáveis pelo contato com instituições privadas, governos, mercados e fornecedores; e, do contato, as conquistas dos meios produtivos necessários para a produção conjunta. Destaca-se como conquista decorrente da atuação neste âmbito, a representação política da comunidade por uma das filhas de Dona Delina, eleita vereadora pelo município de Belo Vale.

O caráter coletivo da produção, do consumo e da apropriação sobre o trabalho gera um princípio de solidariedade entre os membros da comunidade, além de fazer emergir um tipo de simetria entre as partes. Esta simetria deflagra o que Lévesque (2004) denominou como deliberação e governança apropriada, sobretudo pelo caráter determinante de um processo amplamente democrático que tangencia todas as esferas dessa estrutura social.

A comunidade conta também com uma escola, na qual atuam moradores com formação em áreas da educação. Além do currículo regular, a escola conta com aulas sobre a história da comunidade, dança, música e teatro. A escola, bem como todas as outras edificações, foi construída por mutirões formados pelos moradores, e os materiais foram comprados com o lucro das atividades comerciais. A comunidade conta também com casas coletivas, nas quais muitas famílias dividem o mesmo espaço e que abrigam também as refeições servidas para grande parte dos moradores.

Todavia as famílias que optam por residir em casas particulares são apoiadas tanto na aquisição de materiais como no trabalho coletivo (mutirões) para a construção. Os mutirões são comuns na construção civil, na produção agrícola, na produção manufaturada, e em outras atividades esporádicas. Esse traço característico do trabalho na comunidade vem ao encontro do sentimento de reciprocidade, descrito por Polanyi $(2011,2012)$, como modalidade econômica não financeira. 
Figura 3

Mutirão para construção de casas

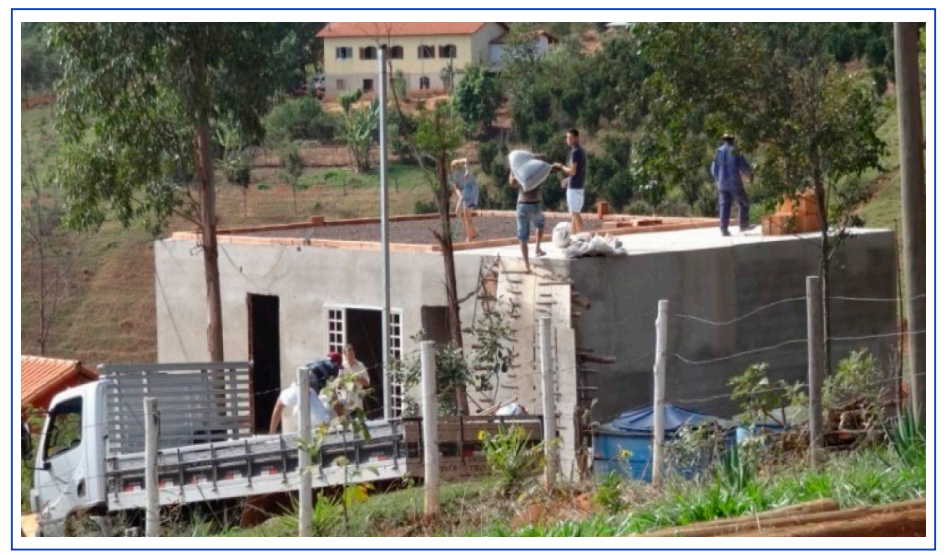

Fonte: Acervo dos autores (2019).

\section{ANÁLISE}

Uma forte característica no sistema econômico da comunidade é a organização dos processos, mesmo na ausência de um sistema normativo formal. As decisões são tomadas segundo as necessidades comunitárias em assembleias frequentes. O grupo delibera informalmente os mais diferentes temas e as áreas responsabilizam-se pela implantação das decisões. Os temas discutidos em assembleia são diversos e englobam principalmente os aspectos produtivos e políticos da comunidade. De acordo com Scott (2010), a ausência de parâmetros religiosos ou políticos que absorvam o excedente torna a pirâmide social mais local e horizontal.

Apesar da organização nos processos, com exceção do estatuto que rege as normas do trabalho associado, tido como pró-forma pelos membros e criado somente para a obtenção de recursos, a comunidade não possui nenhum documento escrito contendo regras ou indicativos de condutas adequadas. Ninguém é formalmente obrigado a nada; todavia, os vínculos agem sobre todos os que ali vivem, guiam os comportamentos e impõem limites morais às condutas. Isso se materializa no padrão dos discursos e dos comportamentos, de crianças a idosos. Nesse sentido, é possível estabelecer uma relação entre dádiva e reciprocidade, que privilegia a doação expressa no trabalho dedicado ao coletivo, independente da ação dos pares. Ao mesmo tempo, receber gera necessariamente o dever de retribuição; no caso, a dedicação a outras atividades coletivas, processos cujas tarefas se realizam de maneira não hierarquizada.

De acordo com Mauss (2008), a criação e a manutenção de vínculos sociais dessa natureza podem ser fortemente atribuídas ao valor e ao significado que são dados às relações sociais. Existe um simbolismo em torno da vida social que garante implicitamente uma obrigação moral entre indivíduos, que, de alguma forma, estabelecem as dádivas. Segundo o autor, as trocas de presentes, de amabilidades e favores, sem contrapartidas ou equivalências exigidas de imediato, estabeleceriam entre os participantes um amplo e duradouro contrato social.

Ao estabelecer e fortalecer historicamente uma constante troca de dádivas, a comunidade logrou a construção de um sistema de prestações e contraprestações de favores e ações voluntárias que agem na manutenção dos vínculos entre os envolvidos no sistema. São esses vínculos que garantem não só a sobrevivência do sistema, como também a reprodução da lógica entre todos que, de alguma forma, o integram ou nele interagem.

Os vínculos estabelecidos e fortalecidos por cada pequena dádiva trocada durante os processos de integração geram em todos os indivíduos da comunidade a reciprocidade, pela sensação pessoal de débito e de crédito com todos que ali vivem. Essa sensação dupla de ter de retribuir tudo o que se recebe do sistema e, ao mesmo tempo, de se sentir merecedor de dádivas retornadas aos poucos - torna extremamente forte cada vínculo pessoal com a comunidade.

Esse comportamento coeso e padronizado surgiu somente no fim da década de 1990, em paralelo às mudanças na lógica produtiva, ou seja, houve uma mudança comportamental induzida por um discurso coletivista, originário de um grupo de 
indivíduos que possuíam influência e autoridade no grupo, que atingiu majoritariamente os indivíduos da comunidade, alterando suas condutas e ações.

O sistema econômico com o nível de coesão comportamental encontrado existe, também, em razão das forças coercitivas internas ao grupo. A ausência de normas formais não retira do grupo a capacidade de inibir potenciais desvios nas condutas e nos discursos. Segundo Mauss (2013), a dívida social seria tanto a garantidora dos vínculos comunitários quanto a causadora da quebra desse vínculo. No processo contínuo de dar-receber-retribuir, a não retribuição gera um descontentamento social que interfere no pertencimento do indivíduo. Na relação de dádiva, o indivíduo não é formalmente obrigado a nada, mas moralmente compelido a retribuir as dádivas recebidas. Quem recebe dádivas e não as retorna de alguma forma pode sofrer sanções sociais, sentir-se excluído e até perder seu vínculo com o todo.

Já a participação intensa no sistema de dádivas gera muitos benefícios ao indivíduo que percebe seu pertencimento aumentar e seus vínculos com o todo. A imagem que alguns membros específicos - como Delina e sua filha Rosalee - possuem de "credores" do sistema é perceptível, tendo origem nas contribuições desses membros para a comunidade - no caso de Delina, em todas as suas ações de formação da comunidade, e no caso de Rosalee, principalmente por seus esforços na política e na conquista da fábrica e do financiamento da terra de plantio.

O sentimento de dívida em relação aos personagens principais da história da comunidade é um dos responsáveis pelo estímulo ao trabalho e à manutenção das atividades coletivas, visto que nenhum membro quer se sentir em dívida com os demais. Dessa forma, todos buscam manter suas contribuições em novas dádivas, seja com seu trabalho, presentes ou gestos fraternais.

Acredita-se que esse seja um dos grandes motivos pelos quais o processo de êxodo rural foi freado. $O$ abandono da comunidade em busca de novas oportunidades, além de não ser interessante por conta dos inúmeros benefícios que ali são providos, pode ser considerado um abandono da lógica comunitária, um afastamento dos princípios da família e, consequentemente, o enfraquecimento dos vínculos com o todo.

Os vínculos observados entre os membros da comunidade vêm não só das dádivas ou dos princípios instaurados em meio ao grupo, mas também de aspectos mais compreensíveis, como vínculos familiares, de vizinhança e de compartilhamento de propriedade. Estes, somados aos aspectos da dádiva e aos princípios de todos, definem o amor como palavra central no discurso dos membros, gerando o anseio de permanência e de contribuição na reprodução do sistema.

Um sistema de dádivas baseia-se na intensidade do sentimento de solidariedade e no cuidado com o próximo. Nesses aspectos, a comunidade Noiva do Cordeiro conta com dinâmicas próprias de auxílio dos membros e de fortalecimento dos vínculos sociais. Primeiramente, no cuidado com as crianças, as quais são assistidas por outras mães e mulheres solteiras, escalonadamente, no período em que elas não estão na escola. Os idosos também recebem uma atenção especial com a ajuda dos jovens que se revezam acompanhando-os durante o dia e, se necessário, passando a noite com eles. O mesmo zelo é reservado aos enfermos, quer seja em suas casas, em algum hospital ou em qualquer outro lugar.

Marcel Mauss (2013) já havia descrito que o recebimento de visitas é algo de grande importância em sistemas inspirados nos aspectos da dádiva. Segundo o autor, é comum que se ofereça o que há de melhor às visitas, superando-se o próprio cotidiano local, segundo o entendimento de que esforços não devem ser poupados nestas circunstâncias. A dádiva se estabelece no nível coletivo, e apresentar coesão e solidariedade do grupo em relação ao outro é um ponto chave no estabelecimento de alianças da comunidade com o seu meio.

Na comunidade Noiva do Cordeiro é possível identificar inúmeras alianças que se formaram por meio desse tipo de relação. Policiais, advogados, políticos, repórteres, pesquisadores, professores, empresários e muitos outros "contatos" foram estabelecidos por meio da amizade e retribuição, frutos do tratamento diferenciado prestado a todos que procuram a comunidade por diferentes razões. É notório o número de alianças instituídas, as quais, em momentos específicos, são retomadas para que a dádiva seja retribuída. A organização do lançamento do CD da dupla sertaneja da comunidade é um caso exemplar. Em busca de fornecedores, muitas ligações foram feitas, e a rede de contatos mostrou-se solícita frente às demandas dos anfitriões. Para o dia da festa, dormitórios foram preparados, colchões e roupas de cama foram distribuídos pelas casas, e até a fábrica e as casas em fase final de construção foram utilizadas como dormitórios para acolher o público.

Godbout (1998) explica que a necessidade de trocas de dádivas viria por si só em busca de se quebrar o isolamento e de se sentir parte de uma identidade. Segundo Mauss $(2008,2013)$, o processo de troca de dádivas não exige que o indivíduo seja demasiadamente bom ou ruim, seria necessário apenas que este agisse sempre levando em conta o seu papel em relação ao 
outro e em relação ao grupo ao qual pertence. Em Noiva do Cordeiro, essa relação é muito evidente, o pensamento coletivo é intenso e intuitivamente todos os integrantes sabem a conduta que devem seguir para não prejudicar o outro, protegendo-se de sanções sociais e da perda de vínculos com o todo. A reciprocidade, portanto, é imprescindível à manifestação da dádiva, embora não de maneira condicionante, mas relativamente cristalizada no comportamento.

Nos sistemas de produção e circulação de bens na comunidade, o processo de troca de dádivas incide de maneira direta na organização de produção, aproximando-se das ideias de reciprocidade segundo Polanyi $(2011,2012)$ em muitos aspectos. A comunidade tem conseguido manter suas próprias relações de trabalho e de distribuição, garantindo seu crescimento e contínuas melhorias na qualidade de vida de seus membros. Seu sistema econômico diferencia-se dos demais modos produtivos da atualidade justamente por conta dos arranjos sociais muito próprios que se desenvolveram na comunidade com o passar dos anos. O reconhecimento no trabalho, o relativo distanciamento das operações de mercado, o fortalecimento da identidade e a formação dos jovens e, principalmente, os mecanismos de coesão e de coerção de condutas são alguns aspectos da forma de sobrevivência e reprodução desse sistema.

Dentro da comunidade, o trabalho se dá sem monetarização, de forma voluntária, ou seja, sem remuneração fixa sobre ele. A renda proveniente dessas atividades é revertida em melhorias da própria comunidade, como na casa mãe, e nas demais compras de consumo coletivo. A participação nas atividades não é obrigatória e nem formal. Muitos indivíduos, por diversas razões, não participam fixamente de nenhum trabalho coletivo, seja por conta da idade, da saúde, ou por viverem fora da comunidade. Mesmo assim, os frutos do trabalho são comunitários, estendendo-se inclusive àqueles impossibilitados de trabalhar. Alimentação, moradia e lazer são garantidos a todos, desde os mais aos menos envolvidos nos trabalhos.

A alimentação, majoritariamente, é comunal. Os insumos básicos são produzidos na própria comunidade, com raras exceções, como óleo, sal, açúcar, farinha de trigo e macarrão. Apesar de haver muitas casas no entorno da casa mãe, poucas são as que preparam suas próprias refeições. A gestão dos recursos da comunidade possui relativa autonomia por intermédio de centros coordenadores das atividades. Cada uma das áreas de trabalho possui um responsável pelas receitas e despesas da atividade e pelo controle de demanda de mão de obra, solicitando auxílio de outras áreas quando necessário, seja financeiramente, seja intelectualmente ou apenas em momentos de necessidade de mão de obra extra.

Figura 4

Separação das pimentas para embalagem na mesa central da Casa Mãe

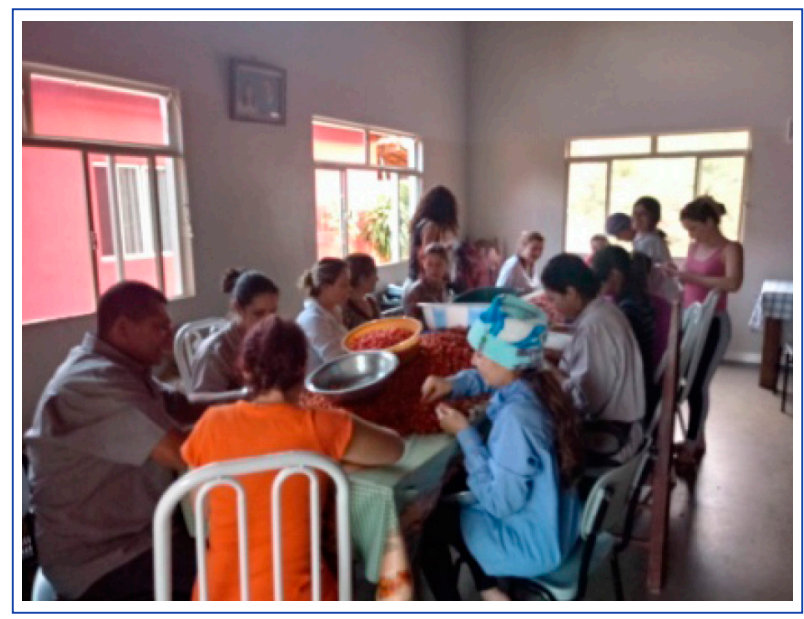

Fonte: Acervo dos autores (2019).

O trabalhador na comunidade possui responsabilidades muito bem definidas pelos grupos de trabalho, e cada indivíduo tem noção do seu papel e da sua responsabilidade no funcionamento do todo, quando decide se engajar nas atividades com as quais tem mais afinidade. A distribuição das atividades baseia-se principalmente nas habilidades e vontades das pessoas, sendo divididas segundo demandas e organizadas mediante pequenas escalas montadas em grupo, ou por WhatsApp, principal meio de comunicação entre os membros. Apesar de a grande parte dos membros da comunidade exercer alguma atividade 
fixa, dificilmente ela vem a preencher todo o tempo, de modo a impedir que a pessoa participe de outras atividades, como as de auxílio a outros membros.

As rendas obtidas individualmente no trabalho externo ficam sob o controle das próprias famílias, porém, como não há gastos significativos no cotidiano da comunidade, o excedente dessa renda acaba passando por um processo de redistribuição mediante as demandas da comunidade ou dos membros que não possuem renda fixa.

Outra forma de ler o processo de reciprocidade na comunidade se dá pela circulação interna da moeda. O uso de moeda e as trocas financeiras são limitados a três estruturas - supermercado, centro de lazer e lojinha de produtos da comunidade regidas pelos conceitos tradicionais de mercado. Entretanto, o lucro gerado nessas estruturas advém dos recursos financeiros conquistados pelos trabalhos externos e pelas famílias em geral, que posteriormente é investido na própria comunidade.

Dentre as formas de aplicação desse lucro, destaca-se o pagamento parcelado dos financiamentos adquiridos para produções coletivas. O restante dos recursos centralizados destina-se a outras demandas, como reformas e construções de novas estruturas na escola para o recebimento do ensino médio; a aquisição de itens básicos para as casas coletivas; a contribuição nas "vaquinhas", arrecadações importantes, como para a construção de novas casas.

Os exemplos citados aproximam-se do que Polanyi $(2011,2012)$ define como esquema de redistribuição e reciprocidade, caracterizado pelo reconhecimento de um centro ao qual os recursos são destinados e, posteriormente, redistribuídos. As "vaquinhas", além de representarem o próprio movimento de redistribuição, ainda podem ser consideradas como estruturas de apoio à reciprocidade para que esta operação ocorra de maneira coordenada e justa. A justiça, nesse caso, também é simbólica, cabendo a cada membro a decisão de solicitar ou não ajuda, e, aos demais, participar ou não do processo.

Em resumo, o Sistema Econômico da Comunidade Noiva do Cordeiro coincide com as linhas centrais de uma economia solidária, substantiva, em que se busca um sistema distinto ao do mercado e da competição como fundamento econômico, colocando no valor da reciprocidade e da redistribuição, junto com o interesse, os três polos econômicos que podem se entrelaçar de maneiras distintas às formas de dádiva e, por consequência, de solidariedade. É esse olhar de uma economia ampla, plural que se pode pensar para evitar seguir os graves custos da desintegração social da economia mercantil (SUBIRATS, 2014).

\section{CONSIDERAÇÕES FINAIS}

Neste trabalho, buscou-se analisar a estrutura social que sustenta um modo de produção e de vida que está muito além das dimensões estritamente mercadológicas. Com o apoio das teorias da sociologia econômica de Marcel Mauss e de Karl Polanyi, foram analisados os aspectos da dádiva e da reciprocidade nas relações produtivas, elementos centrais à reprodução de uma forte lógica solidária.

Constatou-se que os processos encontrados na comunidade Noiva do Cordeiro apresentam-se como alternativas às dinâmicas reprodutoras das diferenças sociais nas sociedades de mercado, corroborando os apontamentos de Polanyi $(2011,2012)$ a respeito da influência das instituições nas operações de troca. O reconhecimento no trabalho, a construção de uma base produtiva e intelectual e os aspectos da sociologia da dádiva em Mauss $(2008,2013)$ foram observados nas relações produtivas e sociais para explicar a manutenção e a reprodução da lógica comunitária.

Ademais, o sentido de família impregnado na comunidade, difundido desde o exemplo de solidariedade e afeto de Dona Delina, matriarca da comunidade, mostrou-se fundamental para o estabelecimento dos padrões de comportamento e de ação coletiva compartilhados entre todos os membros. Destaca-se também o papel da escola da própria comunidade, onde as crianças, além da formação básica, são expostas à história e aos valores como ensinamentos.

As relações de parentesco e de vizinhança incentivaram uma forte cultura de integrações econômicas não financeiras, o que implica, de maneira direta, capacidade de gerar fortes vínculos entre os participantes do sistema. Os vínculos são fortalecidos por conta de uma sólida identidade coletiva e pela reafirmação constante dessa identidade.

A falta de formalização dos processos de trabalho indica pouca preocupação da comunidade em definir a participação de cada indivíduo nas atividades. A ausência de obrigatoriedade estimulou o trabalho em grupo mediante um sentimento constante de reciprocidade e de retorno do esforço despendido. A organização do trabalho e a participação dos membros 
são garantidas por mecanismos sociais ancorados na sensação de pertencimento. O caráter coletivista e a reprodução de condutas complementares da comunidade inibem comportamentos individualistas, bem como afasta parte significativa das características das sociedades capitalistas.

A reboque da assertiva de Sabourin (2008) quanto à não teorização de Mauss a respeito da reciprocidade, elementos cotidianos da comunidade Noiva do Cordeiro permitem afirmar que as organizações de economia solidária são ambientes altamente favoráveis à existência de um sistema de dádivas. Por sua vez, a dádiva pressupõe a reciprocidade, dinâmica expressa no voluntarismo da divisão do trabalho, no acesso comum às mercadorias produzidas em conjunto, no retorno do lucro sobre a venda das mercadorias produzidas para a própria comunidade, no cuidado com as pessoas que demandam mais atenção, dentre outras manifestações.

Todavia a diferenciação do Sistema Econômico da Comunidade Noiva do Cordeiro não apresenta nenhum confronto deliberado à lógica da economia mercantil e à representação política que a sustenta. Baseada em um processo de decisão coletiva, a comunidade define sua representação política, recorre a financiamentos e prospecta negócios com outras organizações, sem abrir mão, no entanto, do equilíbrio social e dos vínculos de troca que a caracterizam.

Sem negar a lógica mercantil, mas aproveitando-se dela para disseminar a sua lógica produtiva própria, a comunidade Noiva do Cordeiro mostra-se como um caso singular no campo das organizações substantivas. Sobretudo por tomar a organização econômica e a divisão do trabalho como potenciais de relações sociais por meio de trocas, em lugar de se caracterizar como uma organização de arranjos produtivos para a acumulação (O'HEARN e GRUBAČIĆ, 2016).

Dessa forma, as práticas constatadas e analisadas contribuem para os estudos de formas organizacionais que se desenvolvem à margem dos sistemas utilitaristas. Ao empreender uma análise baseada nas teorias da dádiva e da reciprocidade do Sistema Econômico da Comunidade Noiva do Cordeiro, o presente trabalho demonstra a realidade de uma forma de organização solidária, reforçando a frutífera possibilidade desta perspectiva para um campo ainda pouco explorado.

\section{AGRADECIMENTOS}

Agradecemos à Coordenação de Aperfeiçoamento de Pessoal de Nível Superior (CAPES) pela bolsa de mestrado concedida ao Luiz Paulo Rigueira de Morais. 


\section{REFERÊNCIAS}

ALVES, J. et al. A economia solidária no centro das discussões: um trabalho bibliométrico de estudos brasileiros. Cadernos EBAPE.BR, v. 14, n. 2, p. 243-257, 2016.

BAHRAMITASH, R. Low-Income Islamic Women, Poverty and the Solidarity Economy in Iran. Middle East Critique, v. 23, n. 3, p. 363377, 2014.

BOROWIAK, C. et al. Navigating the fault lines: Race and class in Philadelphia's Solidarity Economy. Antipode: a radical Journal of geography, v. 50, n. 3, p. 577-603, 2018.

CAILLÉ, A. Antropologia do dom: o terceiro paradigma. Petrópolis: Vozes, 2002.

CALBINO, D.; PAULA, A. Economia Solidária: investigação sobre o estado da arte. Gestão Contemporânea, Porto Alegre, v. 10, n. 14, p. 371-397, 2013.

CARRIER, J. Gifts, commodities, and social relations: a Maussian view of exchange. Sociological Forum, v. 6, n. 1, p. 119-136, 1991.

CASTANHEIRA, E.; PEREIRA, J. Ação coletiva no âmbito da economia solidária e da autogestão. Revista Katálysis, v. 11, n. 1, p. 116-122, 2008.

CHENEY, G. et al. Worker cooperatives as an organizational alternative: challenges, achievements and promise in business governance and ownership. Organisation, v. 21, n. 5, p. 591-603, 2014.

CLIFFORD, J.; GONÇALVES, S. A experiência etnográfica: antropologia e literatura no século XX. Rio de Janeiro: Editora UFRJ, 2011.

CORAGGIO, L. Una lectura de Polanyi desde la economía social y solidaria en América Latina. Cadernos Metrópole, v. 16, n. 31, p. 17-35, 2014.

DARÓS, M. Vínculos sociais e felicidade: um estudo sobre as relações humanas na Economia Solidária. 2016. Tese (Doutorado em Sociologia) - UNISINOS, São Leopoldo-RS, 2016.

DUBCOVÁ, G.; GAJDOVÁ, D.; GRANCICOVÁ, K. Evaluation of the functioning system of the social and solidarity economy in Slovakia. Procedia: Social and Behaviorial Sciences, v. 230, p. 253-264, 2016.

FAVARIN, A. Fundos Rotativos Solidários: Avanços e limites para a construção de finanças solidárias no Brasil. 2018. Tese (Doutorado em Sociologia) - UFSC, Santa Catarina, 2018.

FAZENDEIRO, S. Espiritualidade e subjetividade: um estudo sobre a transmissão dos valores espirituais na comunidade Noiva do Cordeiro. 2016. Dissertação (Mestrado em Ciência da Religião) - PUC-MG, Belo Horizonte, 2016.

FERRARINI, A.; GAIGER, L.; SCHIOCHET, V. O estado da arte e a agenda de pesquisa em economia solidária no Brasil. Revista Brasileira de Sociologia, v. 6, n. 12, p.157-180, 2018.

FRANÇA FILHO, G. A problemática da economia solidária: um novo modo de gestão pública? Cadernos EBAPE.BR, v. 11, n. 3, p. 443461, 2004.

FRANÇA FILHO, G.; DZIMIRA, S. Economia solidária e dádiva. Organizações \& Sociedade, v. 6, n. 14, p. 141-183, 1999.

GERMAIN, L. Solidarity economy in Montreal: woman's activism creating alternatives through the Ethics of care. 2010. Dissertação (Mestrado em Artes) - Condordia University, Montreal, 2010.
GODBOUT, T. Introdução à dádiva. Revista Brasileira de Ciências Sociais, São Paulo, v. 13, n. 38, p. 39-51, 1998.

GRAEBER, D. On the moral grounds of economic relations: a Maussian approach. Journal of Classical Sociology, v. 14, n. 1, p. 65-77, 2014.

GRANOVETTER, M. Le marché autrement: essais de Mark Granovetter. Paris, Desclée de Brouwer, 2000.

HUDSON, L. New York City: Struggles over the narrative of the Solidarity Economy. Geoforum, v. 95, 2018.

KALOGERAKI, S.; PAPADAKY, M.; ROS, M. Exploring the social and solidarity economy sector in Greece, Spain, and Switzerland in Times of Crisis. American Behavioral Scientist, v. 62, n. 6, p. 856-874, 2018.

$\mathrm{KIRSCH}, \mathrm{R}$. Incubação de Empreendimentos da Economia Solidária e as implicações das relações de reciprocidade. 2007. Dissertação (Mestrado em Sociologia), Universidade de Brasília, Brasília, DF, 2007.

KIRSCHNER, M.; MONTEIRO, C. Da sociologia econômica à sociologia da empresa: para uma sociologia da empresa Brasileira. Sociedade e Estado, v. 17, n. 1, p. 80-103, 2002.

KUMBAMU, A. Building sustainable social and solidarity economies: place-based and network-based strategies of alternative development organizations in India. Community Development, v. 49, n. 1, p. 18-33, 2018.

LAVILLE, J. L'économie solidaire: une perspective internationale. Paris: Desclée de Brouwer, 1994.

LAVILLE, J. Mudança social e teoria da economia solidária. Uma perspectiva maussiana. Sociologias, v. 16, n. 36, p. 60-73, 2014.

LAVILLE, J. Repensando o espaço público e a economia: contribuição da economia solidária à teoria da democracia. Organizações \& Sociedade, v. 23, n. 78, p. 369-377, 2016.

LÉVESQUE, B. Contribuição da nova sociologia econômica para repensar a economia no sentido do desenvolvimento sustentável. Revista de Administração de Empresas, v. 47, n. 2, p. 49-60, 2007.

LÉVESQUE, B. Les enjeux du développement et de la démocratie dans les pays du Nord: l'expérience du Québec. In: FALL, A.; FAVREAU, L.; LAROSE, G. (Orgs.). Le Sud...et le Nord dans la mondialisation: quelles alternatives? Québec: Presses de I'Université du Québec, 2004. p. 97-132.

LOH, P.; AGYEMAN, J. Urban food sharing and the emerging Boston food solidarity economy. Geoforum, v. 99, 2018.

MACHADO, S.; NASCIMENTO, M. A utilização do termo imersão social nas pesquisas em administração. Caderno de Administração, Maringá, v. 18, n. 2, p. 54-61, 2012.

MAGALHÃES, G.; SANTOS, L.; BOEIRA, L. Etnografia e estudos organizacionais: análise da produção científica brasileira. Revista Brasileira de Estudos Organizacionais, v. 3, n. 2, p. 145-170, 2016.

MARTES, A. et al. Fórum: Sociologia Econômica. Revista de Administração de Empresas - Eletrônica, v. 6, n. 1, p. 4, 2007.

MATSUI, N.; IKEMOTO, Y. Solidarity Economy and Social Business: new models for a New Society. Springer Tokyo Heidelberg, 2015. 
MATTOS, L. A abordagem etnográfica na investigação científica. In: MATTOS, L.; CASTRO, A. (Orgs.). Etnografia e educação: conceitos e usos. Campina Grande: EDUEPB, 2011. p. 49-83.

MAUSS, M. Ensaios de sociologia. São Paulo: Perspectiva, 2013.

MAUSS, M. Ensaio sobre a dádiva. Lisboa: Edições 70, 2008.

MOREIRA, H. Contribuição da nova Sociologia Econômica para a Administração no Brasil. 2016. Dissertação (Mestrado Profissional em Administração) - Fundação Getulio Vargas, Rio de Janeiro, 2016.

OGANDO, B. Economia solidária e desigualdades: uma análise a partir da sociologia econômica. 2011. Dissertação (Mestrado em Sociologia) - Universidade Federal de Santa Catarina, Santa Catarina, 2011.

O'HEARN, D.; GRUBAČIĆ, A. Capitalism, mutual aid, and material life: understanding exilic spaces. Capital \& Class, v. 40, n. 1, p. 147165, 2016.

PAPADAKI, M.; KALOGERAKI, S. Exploring social and solidarity economy during the Greek economic crisis. The open Journal of Sociopolitical Studies, v. 11, n. 1, p. 38-69, 2018.

PARKER, M. et al. Routledge Companion to Alternative Organisations. London: Routledge, 2014.

PINHEIRO, D. Economia Solidária: Uma Revisão Teórica a Partir dos Seus “Múltiplos" Conceitos. NAU Social, v. 3, n. 5, p. 85-105, 2013.

PINHEIRO, D. O Estado da arte da produção científica em economia solidária. Administração Pública e Gestão Social, v. 8, n. 2, p. 95 103, 2016.

POLANYI, K. A grande Transformação: as origens da nossa época. Rio de Janeiro: Campus, 2011.

POLANYI, K. A subsistência do homem e ensaios correlatos. Rio de Janeiro: Contraponto Editora, 2012.

RIGO, A.; FRANÇA FILHO, G. O paradoxo das Palmas: análise do (des)uso da moeda social "no bairro da economia solidária". CadernosEBAPE.BR, v. 15, n. 1, p. 169-193, 2017.

ROESE, A. Vida sem religião: o caso da "comunidade de mulheres" Noiva do Cordeiro. In: ROSADO, M. (Org.). Gênero, feminismo e religião: Sobre um campo em constituição. Rio de Janeiro: Garamond, 2015. p. 35-50.

ROESE, A.; SCHULTZ, A. Modos de vida alternativos: o caso da comunidade Noiva do Cordeiro. Revista Tecer, Belo Horizonte, v. 3, n. 5, nov. 2010.
SABOURIN, E. Marcel Mauss: da dádiva à questão da reciprocidade. Revista Brasileira de Ciências Sociais, v. 23, n. 66, p. 131-138, 2008.

SATGAR, V. Challenging the globalized agro-food complex: farming cooperatives and the emerging solidarity economy alternative in South Africa. Working USA: The journal of labor and society, v. 14, p. 177-190, jun. 2011.

SCHNEIDER, S.; ESCHER, F. A contribuição de Karl Polanyi para a sociologia do desenvolvimento rural. Sociologias, v. 13, n. 27, p. 180-219, 2011.

SCHULTZ, A. Pós-protestantismo: descrição e análise de um caso de dissidência religiosa na comunidade rural Noiva do Cordeiro, em Belo Vale, MG. Protestantismo em Revista, São Leopoldo, v. 30 p. 104-123, 2013.

SCOTT, J. The art of not being governed: an anarchist history of upland Southeast Asia. New Haven: Yale University Press, 2010.

SERVA, M. Contribuições da sociologia econômica à teoria das organizações. Sociedade e Estado, Brasília, v. 17, n. 1, p. 10622,2002

SERVA, M.; ANDION, C. Teoria das organizações e a nova sociologia econômica: um diálogo interdisciplinar. Revista de Administração de Empresas, São Paulo, v. 46, n. 2, p. 10-21, jun. 2006.

SOBEL, R.; POSTEL, N. Formal economy, substantive economy, and economism: a critical interpretation of Karl Polanyi's distinction. Philosophy of the Social Science, v. 46, n. 5, p. 473-497, 2016.

STOREY, J.; BASTERRETXEA I.; SALAMAN, G. Managing and resisting 'degeneration' in employee-owned businesses: a comparative study of two large retailers in Spain and the United Kingdom. Organisation, v. 21, n. 5 , p. 626-644, 2014

SUBIRATS, J. Acerca del renovado interés por Karl Polanyi. Cadernos EBAPE.BR, v. 12, n. 2, p. 199-205, 2014.

SWEDBERG, R. Une histoire de la sociologie économique. Paris: Desclée de Brouwer, 1994.

TRAVANCAS, S. Fazendo etnografia no mundo da comunicação. In: DUARTE, J.; BARROS, A. (Orgs.). Métodos e técnicas de pesquisa em comunicação. São Paulo: Editora Atlas, 2006. p. 99-109.

VIZEU, F. Contribuições da sociologia da dádiva aos estudos sobre organizações substantivas. Organizações \& Sociedade, v. 16, n. 50, p. 409-427, 2009. 
Luiz Paulo Rigueira de Morais

ORCID: https://orcid.org/0000-0002-6573-3366

Mestre em Administração pela Universidade Federal de Viçosa (UFV), Viçosa - MG, Brasil. E-mail: Iprmorais@gmail.com

Wescley Silva Xavier

ORCID: https://orcid.org/0000-0003-3524-3566

Doutor em Administração pela Universidade Federal de Minas Gerais (UFMG); Professor Adjunto da Universidade Federal de Viçosa (UFV),

Viçosa-MG, Brasil. E-mail: wescley@ufv.br

Daniel Calbino Pinheiro

ORCID: https://orcid.org/0000-0001-8260-6126

Doutor em Administração pela Universidade Federal de Minas Gerais (UFMG); Professor Adjunto da Universidade Federal de São João del-Rei (UFSJ), Sete Lagoas - MG, Brasil. E-mail: dcalbino@ufsj.edu.br 